\title{
Review \\ The Impact of Chatbots on Customer Loyalty: A Systematic Literature Review
}

\author{
Liss Jenneboer ${ }^{1, *}$, Carolina Herrando ${ }^{2}\left[\right.$ and Efthymios Constantinides ${ }^{3}(\mathbb{C})$ \\ 1 Department of Communication Science, University of Twente, 7522NH Enschede, The Netherlands \\ 2 Department of Marketing, University of Zaragoza, 50009 Zaragoza, Spain; cherrando@unizar.es \\ 3 Department High-Tech Business and Entrepreneurship, University of Twente, \\ 7522NH Enschede, The Netherlands; e.constantinides@utwente.nl \\ * Correspondence: 1.jenneboer@student.utwente.nl or liss_jenneboer@hotmail.com
}

check for

updates

Citation: Jenneboer, L.; Herrando, C.; Constantinides, E. The Impact of Chatbots on Customer Loyalty: A Systematic Literature Review. J. Theor. Appl. Electron. Commer. Res. 2022, 17, 212-229. https://doi.org/10.3390/ jtaer17010011

Academic Editor:

Eduardo Álvarez-Miranda

Received: 9 December 2021

Accepted: 17 January 2022

Published: 21 January 2022

Publisher's Note: MDPI stays neutral with regard to jurisdictional claims in published maps and institutional affiliations.

Copyright: (C) 2022 by the authors. Licensee MDPI, Basel, Switzerland. This article is an open access article distributed under the terms and conditions of the Creative Commons Attribution (CC BY) license (https:// creativecommons.org/licenses/by/ $4.0 /)$

\begin{abstract}
More and more companies have implemented chatbots on their websites to provide support to their visitors on a $24 / 7$ basis. The new customer wants to spend less and less time and therefore expects to reach a company anytime and anywhere, regardless of time, location, and channel. This study provides insight into the influence of chatbots on customer loyalty. System quality, service quality, and information quality are crucial dimensions that a chatbot must meet to give a good customer experience. To make a chatbot more personal, companies can alter the language style. Human-like chatbots lead to greater satisfaction and trust among customers, leading to greater adoption of the chatbot. The results of this study showed that a connection between chatbots and customer loyalty is very likely. Besides, some customers suffer from the privacy paradox because of personalization. Implications of this study are discussed.
\end{abstract}

Keywords: chatbots; trust; satisfaction; commitment; customer experience; loyalty; service quality; digital marketing; information quality; privacy

\section{Introduction}

In the current era, wherein consumers spend more and more time in digital environments, companies prioritize being online anytime and anywhere to keep in touch with their customers [1]. In this digital age, customers have the opportunity to choose from numerous companies that provide the same service or product. As a result of this growing offer, consumers can afford to be choosy [2]. Companies are constantly challenged by competition to attract and retain customers to increase customer experience and thereby customer satisfaction [3]. Online communication is an essential factor in improving the customer experience [3]. A personal approach in digital customer contact is vital concerning the customer and the preservation thereof [3]. According to Siswi and Wahyono [4], satisfaction is created by meeting customer expectations. By optimizing the customer experience, customer expectations and satisfaction can be exceeded. Customer satisfaction leads to customer loyalty, which has been important for decades [5].

Due to digital developments and growing competition, companies are constantly challenging to attract and retain customers [1]. The 'new customer in 2021' wants to spend less and less time and therefore expects to be able to reach a company anytime and anywhere, regardless of time, location, and channel [2]. An instrument to respond to digitization and customer experience is the use of chatbots [6]. Offering visitors an additional means of communication increases customer contact [2]. By responding proactively as a company to questions and complaints from a customer, the customer receives a feeling of confidence and satisfaction [7]. Partly due to the use of a chatbot, a customer gains more confidence in an organization, leading to customer loyalty. The purpose of this study is to provide insight into the role of chatbots by increasing customer loyalty. This study attempts to 
answer the following research question: "To what extent do chatbots contribute to increasing customer loyalty?"

The topic of this study is partly inspired by the MSI Research Priorities [8], wherein customer experience and loyalty were frequently mentioned. Customer loyalty is one of the most critical factors for a company to increase its market share and, therefore, interesting to investigate further [9]. There exist many studies on traditional customer loyalty. With the ever-innovating and growing digital world, it is interesting to study customer loyalty in the digital world $[10,11]$. Chatbots are an emerging development and are found to be interested in this study. There exist some studies about the relation between chatbots and customer satisfaction, but the connection between chatbots and customer loyalty is not frequently made. Besides, the existing studies are based on consumer support by humans and not by chatbots.

This study aims to provide insight into the role of chatbots by increasing customer loyalty. While in the past, companies could only reach their local customers through faceto-face contact or mass media, technology made it possible that companies are nowadays able to have online contact with their customers all day long. Therefore, companies prioritize being online anytime and anywhere to respond to the online competition and keep in touch with their customers to provide them with a satisfying online service and experience [12]. As stated earlier, customer loyalty has been playing an essential role for years. However, the way to achieve this has changed over the years due to online competition and technological developments. Stating this, in this digital age where the continuous availability of businesses is crucial, optimizing the customer experience is more important than ever before [11]. Proactive and personal customer contact is a significant factor in the customer experience. A chatbot can respond to this by proactively and quickly responding to customer questions. This study tries to close the academic gap between customer loyalty and chatbots. The academic impact of this study is that there is limited research on the effect of chatbots on customer loyalty. This study provides more insight into customer loyalty and its underlying dimensions, and how chatbots can respond to the changing needs of today's customers to achieve customer loyalty. To reach the aim of this study, a Systematic Literature Review is conducted.

This study contributes to providing companies with some insights about the use of chatbots as a tool for customer service. As mentioned earlier, reasonable assistance and fast service lead to customer satisfaction, which in turn leads to customer loyalty. Customer loyalty leads to a higher market share [9]. A chatbot can also serve several customers at the same time, which lowers costs. That makes it attractive for companies to obtain more information about chatbots. According to Gartner [13]. more and more companies are using chatbots to serve their customers. This research seeks to help companies understand the role of chatbots by increasing their customer loyalty, resulting in higher profits [9].

\section{Theoretical Background}

\subsection{Customer Loyalty}

Customer loyalty has been playing a critical role for decades [14] Customer loyalty is the degree to which a customer remains loyal to a customer in terms of attitude and behavior even when there are alternatives from other suppliers [14]. For many organizations, customers who regularly make repeat purchases are of great value. The cost of attracting a new customer is many times higher than the cost of retaining a customer. In addition, a returning customer ensures a higher average customer value. This outlines the importance of customer loyalty [15].

According to previous studies [16,17] three main drivers play a role in realizing customer loyalty: the trust of the customer [18] the satisfaction of the customer [19], and commitment [20]. Figure 1 illustrates the relationship between customer loyalty, satisfaction, trust, and commitment. As Figure 1 defines, customer satisfaction is about the satisfaction of customers with a company's products, services, and capabilities in the past [19]. Trust refers to the-future-trust of a consumer in a brand [18] Customer commitment is related 
to a customer's engagement or continuous obligation to return to the same company and invest in the relationship [19].

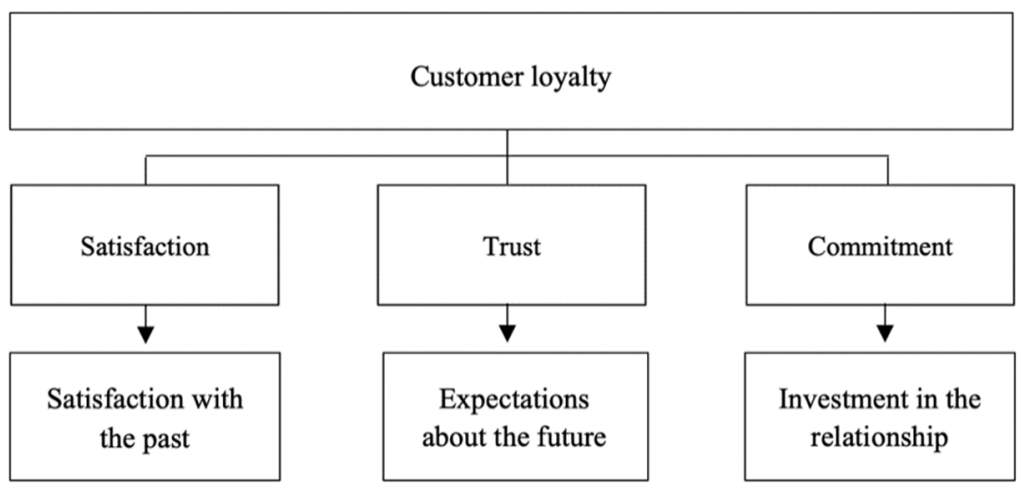

Figure 1. Drivers of customer loyalty.

The three main drivers of customer loyalty influence behavioral loyalty and attitude loyalty [21]. Customer (behavior) loyalty is important because it is less expensive to retain customers than to seek new ones [19]. Retained customers are expected to increase their willingness to make more purchases from a particular organization [22]. Additionally, loyal customers could create potential positive word-of-mouth advertising [23], referring to attitude loyalty [20] Researchers such as Hallowell [7] and Lake [24] stated a significant relationship between customer satisfaction and loyalty which turns to profitability.

\subsection{Chatbots}

It is crucial to approach the customer at the right time and address them personally [25]. An accessible way of doing this is through seeking contact with the company by using a chatbot, ensuring a better customer experience [26,27]. Figure 2 visualizes how the quality of the chatbot can lead to customer experience. A company's chatbot that wants to offer the customer a good experience in information systems complies with service quality, system quality, and information quality [28].

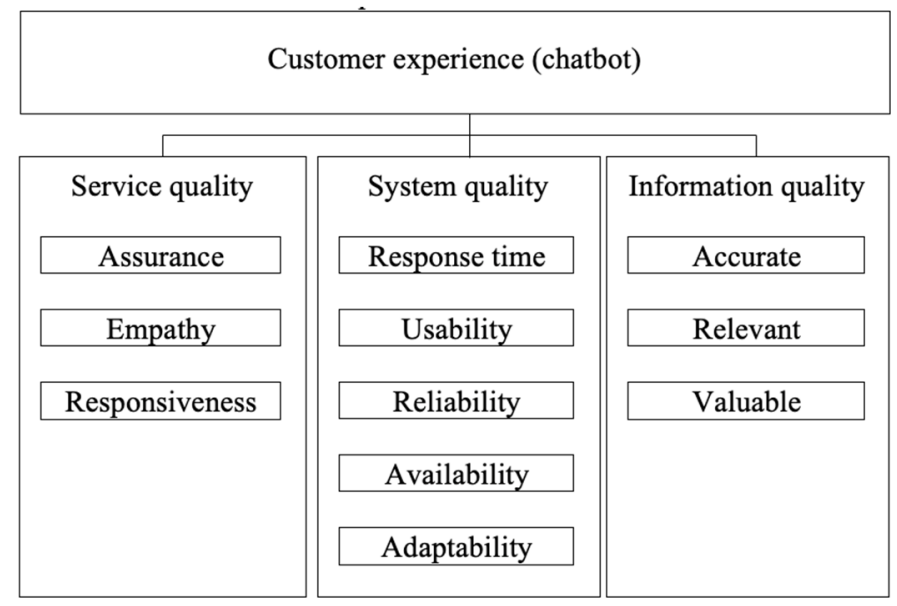

Figure 2. Customer experience and its dimensions by chatbots.

Service quality is critical for organizations because it impacts the customer experience of a customer [29]. A good customer experience can raise customers' satisfaction, trust, and commitment, which leads to loyalty and purchase intentions of customers. Assurance, responsiveness, empathy are the underlying dimensions of service quality [29]. Assurance refers to professional problem-solving and communication skills when helping customers 
out with their issues. Responsiveness is related to the quick provision of services to the customer, and lastly, empathy is all about understanding the customers' needs [29].

The dimension of system quality consists of the five dimensions of response time, usability, reliability, availability, and adaptability to measure the technical success of the chatbot. Response time is all about how long it takes before a message is answered. Usability is about the ease of use of an information system, such as a chatbot. The chatbot needs to be reliable to have the possibility to use it anytime and anywhere. Adaptability tells more about the ability to keep up with the changing developments [29]. The dimension of information quality is about providing a customer with accurate, relevant, and valuable information at the right moment [29].

With chatbots, consumers' questions and complaints could be answered in real-time and make organizations less likely to lose sight of the customer [30]. According to Chung and colleagues, chatbots provide a new layer of support-and complaint handling-for the dimension of service quality by ensuring that-due to the digitalization-personalized service is available to meet customer needs anytime, anywhere [31]. However, due to digitalization, customers are having concerns about the exposure of personal information. At the same time, those concerns fade into the background in the face of a reward or offer [32]. An article by Gartner [13] stated that chatbots could manage customer progress more effectively than humans using efficient decision trees. Factors as helpful (virtual) employees, fast service, personality, factual information, and service quality affect the customer experience [33]. When customer expectations are exceeded, customer satisfaction can be converted into customer loyalty [7].

\section{Materials and Methods}

This systematic literature review performs a systematic search based on scientific literature and other documents to answer a scientific question, which means that only desk research is used. A systematic review follows a clearly defined plan where the criteria are clearly stated before the review is conducted. It is a comprehensive, transparent search conducted over databases and literature that can be replicated and reproduced by other researchers. The review identifies the type of information searched, critiqued, and reported within known timeframes. The search terms, search strategies (including database names, platforms, dates of search) and limits all need to be included in the review.

Throughout this study, an ongoing review of the literature is undertaken, which includes books, scholarly articles, and reports. The aim was to gain insight into the relationship between chatbots and customer loyalty by studying existing literature on chatbots, customer experience, and customer loyalty.

To search the relevant literature for the review, we made use of the Scopus-database. A distinction and combination are made between customer loyalty and chatbots in the selection process to find relevant literature to answer the research question. The selection process is based on search words and selection criteria. Several selection criteria are used to filter relevant literature for this study. The inclusion criteria entailed (1) determining the search boundaries, (2) identifying the search string, and (3) specifying the timeframe [34].

The selected timeframe for customer loyalty is 1990-2021 because customer loyalty has been around for years, and due to the growing offers on the web, it has become more difficult for organizations to retain customers [2]. The first chatbot, named Eliza, was introduced in 1966, and from here, many followed [35]. Although some chatbots were already developed before 2010, the chosen publication date of papers about chatbots is after 2010-since they developed over time. In 2010, the virtual assistant Siri was launched and set the tone for all the other virtual device assistants that followed [36]. The criteria of publication date ensure that articles from the early period of both topics can be included, but also to select literature that provides current information.

Based on the exclusion criteria, the initial papers were further analyzed. Selected literature should be written in English, which means that papers that were not written in English were excluded. Non-academic articles were eliminated; thus, only academic 
journal and conference articles have been chosen because this guarantees a certain level of quality and reliability. Additionally, news articles from particular websites with up-to-date information can be selected as chatbots are an emerging development.

First, the suggested papers $(n=137)$ were on Scopus, and other sources were selected based on screening their records. During this process, 33 articles were yielded. Second, the selected papers $(n=104)$ were based on their full text, assessed for eligibility, which reduced the initial list to a smaller set of $(n=41)$ articles. The keywords are listed in Table 1.

Table 1. Systematic Literature Review search words.

\begin{tabular}{|c|c|c|c|c|c|}
\hline $\begin{array}{l}\text { ScopusSearch } \\
\text { Words }\end{array}$ & Hits & $\begin{array}{l}\text { Papers } \\
\text { Selected } \\
\text { Based on } \\
\text { Abstract }\end{array}$ & $\begin{array}{c}\text { Additional } \\
\text { Related Papers } \\
\text { Selected Based } \\
\text { on Abstract }\end{array}$ & $\begin{array}{c}\text { Papers } \\
\text { Excluded } \\
\text { after Reading } \\
\text { the Full Text }\end{array}$ & $\begin{array}{c}\text { Total } \\
\text { Chosen } \\
\text { Papers }\end{array}$ \\
\hline $\begin{array}{l}\text { "customer loyalty" } \\
\text { AND chatbot* }\end{array}$ & 5 & 3 & 9 & 4 & 8 \\
\hline $\begin{array}{l}\text { "customer experience" } \\
\text { AND chatbot * }\end{array}$ & 35 & 20 & 12 & 22 & 14 \\
\hline $\begin{array}{l}\text { "customer satisfaction" } \\
\text { AND chatbot * OR } \\
\text { "virtual assistant" }\end{array}$ & 42 & 21 & 9 & 17 & 16 \\
\hline "loyalty" AND chatbot* & 4 & 1 & 0 & 1 & 0 \\
\hline
\end{tabular}

Figure 3 visualizes the systematic literature review process. The last step of the systematic literature review process included investigating the content of the articles to filter the most relevant papers of all the papers.

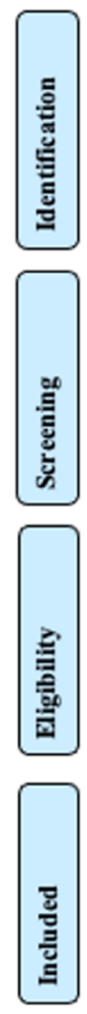

Records identified through database searching $(\mathrm{n}=141)$
Additional records identified through other sources $(\mathrm{n}=24)$
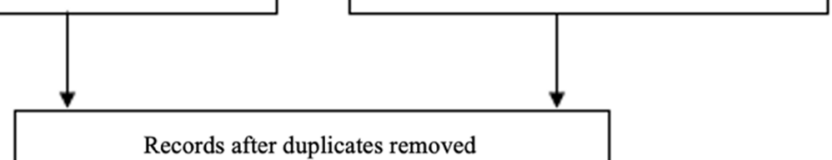
$(\mathrm{n}=137)$

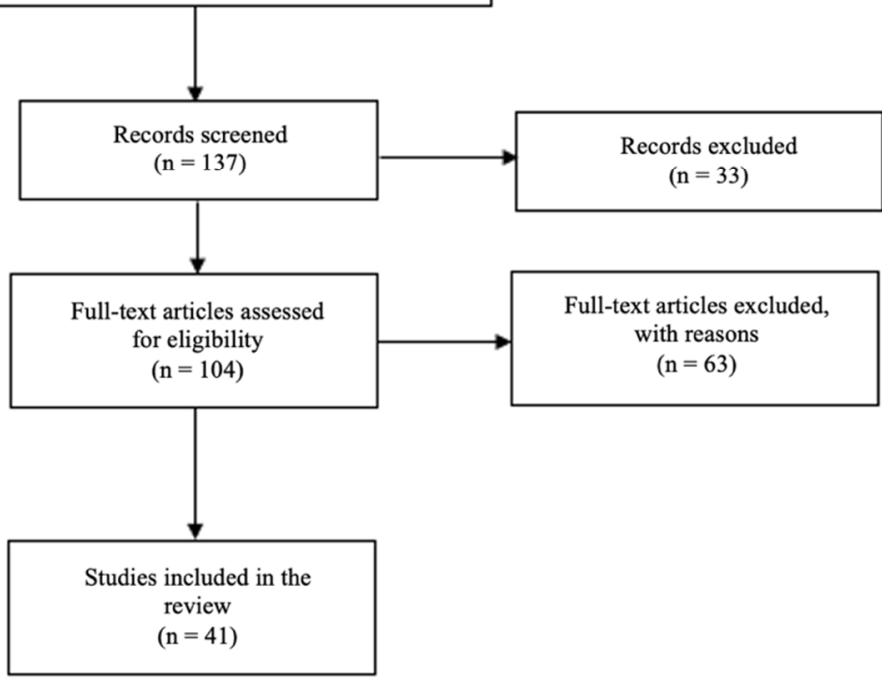

Figure 3. Systematic literature review process. 


\section{Results}

Table 2 provides insights into the nine primary constructs based on the literature of the chosen articles. Table 2 serves as guidance wherein the constructs are defined, the related articles, and the key findings. Consumer trust, customer satisfaction, and customer commitment are because of the literature seen as constructs of customer loyalty. The constructs of service quality, system quality, and information quality belong to chatbots since these dimensions are seen as predictors of customer experience concerning chatbots. The constructs of personalization, privacy paradox, and customer complaint are seen as overlapping constructs and, therefore, not connected to customer loyalty or chatbots. The last two columns include the future research and practical implications, which are further explained in the discussion portion.

\subsection{Descriptive Analysis}

The selected papers of the systematic literature research are about customer loyalty, chatbots, and most of them cover both topics. As described earlier in the method section, 41 papers were selected to conduct this systematic literature review. The selected papers together provide a wide range of the dimensions of customer loyalty and the experiences among chatbots. Figure 4 highlights the investigated topics, where several papers are related to the dimensions of chatbots and loyalty and therefore belong to more than one topic. As Figure 4 illustrates, many papers referred to customer trust, satisfaction, and service quality to create customer loyalty.

\section{Topics}

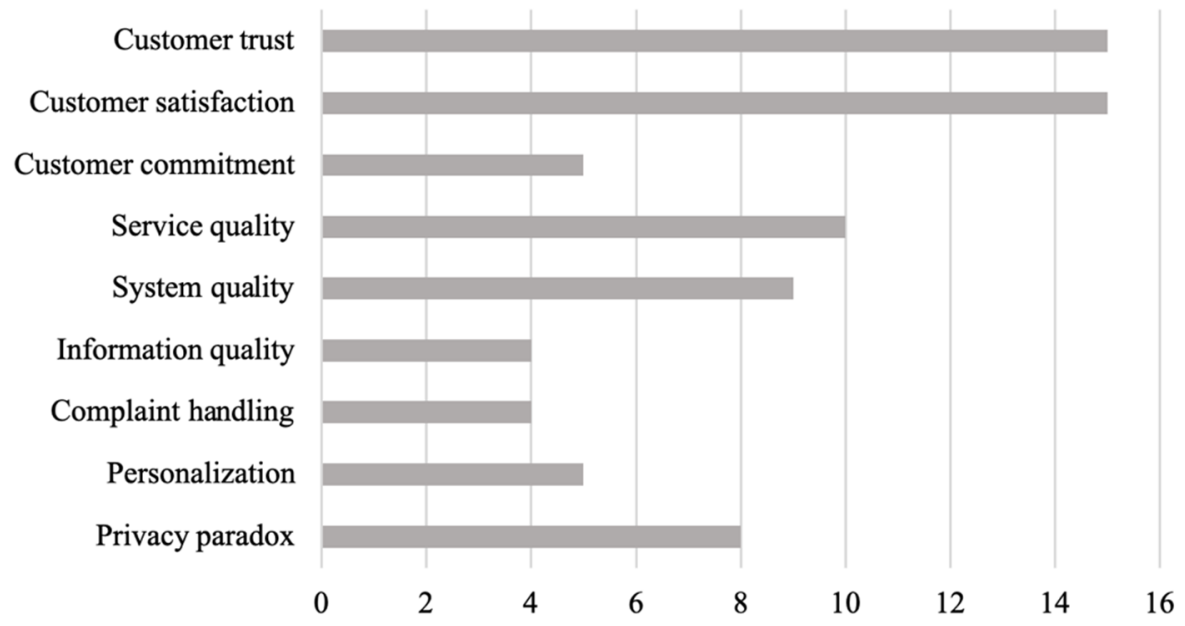

Figure 4. Topics of the selected papers.

Figure 5 provides insights into the publication years of the used papers. During this systematic literature review, the search words were all based on the connection between customer loyalty and chatbots. Most of the found papers were between 2018 and 2021. As mentioned earlier, the market of chatbots is on the rise, and companies are trying to challenge the competition online, which might be the reason for more studies having occurred during these years.

Finally, Figure 6 visualizes the five journals that were used the most. The figure shows that the Journal of Computers in Human Behavior was used most frequently, followed by the Journal of Psychology and Marketing, the Journal of Chatbot Research and Design, the Journal of Business Research, and the Journal of Marketing. 
Table 2. Customer loyalty and chatbots construct summary.

\begin{tabular}{|c|c|c|c|c|c|}
\hline Construct & Definition & Found Articles & Findings/Comments & Future Research & Practical Implications \\
\hline $\begin{array}{l}\text { Customer loyalty: } \\
\text { Customer trust } \\
\text { Included in } 17 \text { studies }\end{array}$ & $\begin{array}{l}\text { Trust of a customer in a } \\
\text { brand [18]. }\end{array}$ & $\begin{array}{l}\text { Hallowell [7]; Van Vuuren et al. } \\
\text { [17]; Bryant and Colledge [18]; } \\
\text { Mende et al. [26]; Sidaoui et al. } \\
\text { [27]; Yen and Chiang [37]; Akhtar } \\
\text { et al. [38]; Ba and Johansson [39]; } \\
\text { Følstad and Skjuve [40]; } \\
\text { Kormpho et al. [41]; Przegalinska } \\
\text { et al. [42]; Araujo [43]; } \\
\text { Chattaraman et al. [44]; Toader } \\
\text { et al. [45]; Følstad et al. [46]; } \\
\text { Youn and Jin [47]; } \\
\text { Nguyen et al. [48]. }\end{array}$ & $\begin{array}{l}\text { Initial evidence that chatbots with } \\
\text { human-like cues can significantly } \\
\text { influence emotional connection } \\
\text { and users' trust. The same outcome } \\
\text { is not found for satisfaction. for } \\
\text { chatbots, trust is a crucial factor } \\
\text { because users do not want to share } \\
\text { personal information if they have } \\
\text { trust concerns. }\end{array}$ & $\begin{array}{l}\text { The chatbot and its trust } \\
\text { reduction may be more } \\
\text { efficient in complex websites } \\
\text { or with older people. That } \\
\text { needs further research. }\end{array}$ & $\begin{array}{l}\text { Companies should put } \\
\text { into winning customers' } \\
\text { trust by sharing reviews } \\
\text { and being transparent. }\end{array}$ \\
\hline $\begin{array}{l}\text { Customer loyalty: } \\
\text { Customer satisfaction } \\
\text { Included in } 12 \text { studies }\end{array}$ & $\begin{array}{l}\text { Satisfaction of customers with } \\
\text { company's products, services, } \\
\text { and capabilities [19]. }\end{array}$ & $\begin{array}{l}\text { Van Vuuren [17]; Herrmann et al. } \\
\text { [19]; Yen and Chiang [37]; } \\
\text { Følstadt and Skjuve [40]; } \\
\text { Kormpho et al. [41]; Araujo [43]; } \\
\text { Youn and Jin [47]; Gnewuch et al. } \\
\text { [49]; Rossmann et al. [50]; } \\
\text { Hwang et al. [51]; Elsholz et al. } \\
\text { [52]; Johari et al. [53]. }\end{array}$ & $\begin{array}{l}\text { Chatbots have a more substantial } \\
\text { impact on word-of-mouth and } \\
\text { reuse intent, while customer } \\
\text { satisfaction obtained through } \\
\text { traditional customer service has a } \\
\text { stronger impact on customer } \\
\text { loyalty. }\end{array}$ & $\begin{array}{l}\text { The most important thing for } \\
\text { customer satisfaction is } \\
\text { helping the customer out and } \\
\text { giving them a good } \\
\text { experience. Studies found } \\
\text { that chatbots improve the } \\
\text { customer experience. } \\
\text { Investigate the relationship } \\
\text { between loyalty and chatbots. }\end{array}$ & $\begin{array}{l}\text { Optimize the customer } \\
\text { experience to raise } \\
\text { customer satisfaction. }\end{array}$ \\
\hline $\begin{array}{l}\text { Customer loyalty: } \\
\text { Customer } \\
\text { commitment } \\
\text { Included in } 4 \text { studies }\end{array}$ & $\begin{array}{l}\text { Customers' engagement or } \\
\text { continuous obligation to return } \\
\text { to the same company [20]. }\end{array}$ & $\begin{array}{l}\text { Van Vuuren et al. [17]; Kotler and } \\
\text { Armstrong [20]; Trivedi [29]; } \\
\text { Akhtar et al. [38]; Araujo [43]. }\end{array}$ & $\begin{array}{l}\text { Customer loyalty can only happen } \\
\text { if companies can build an } \\
\text { emotional relationship with their } \\
\text { customers. }\end{array}$ & $\begin{array}{l}\text { Further analyze the role of } \\
\text { the language of chatbots to } \\
\text { create commitment. }\end{array}$ & $\begin{array}{l}\text { Focus on social bonding } \\
\text { tactics to improve } \\
\text { customer commitment. }\end{array}$ \\
\hline $\begin{array}{c}\text { Chatbots: } \\
\text { Service quality } \\
\text { Included in } 10 \text { studies }\end{array}$ & $\begin{array}{l}\text { Service quality is essential for } \\
\text { companies because it influences } \\
\text { customers' satisfaction, loyalty, } \\
\text { and purchase intentions. } \\
\text { Assurance, responsiveness, and } \\
\text { empathy are the dimensions of } \\
\text { service quality [29]. }\end{array}$ & $\begin{array}{l}\text { Brandtzaeg and Følstad [5]; } \\
\text { Hoyer et al. [10]; Trivedi [29]; Yen } \\
\text { and Chiang [37]; Kormpho et al. } \\
\text { [41]; Følstad and Skjuve [40]; } \\
\text { Følstad et al. [46]; Nguyen et al. } \\
\text { [48]; Rossmann et al. [50]; Ashfaq } \\
\text { et al. [54]; Kvale et al. [55]. }\end{array}$ & $\begin{array}{l}\text { Service quality positively affects } \\
\text { customer experience, which in turn } \\
\text { influences brand love. Chatbots } \\
\text { impact stronger on word-of-mouth } \\
\text { and intention to reuse, whereas } \\
\text { customer satisfaction derived by a } \\
\text { hotline is affecting stronger on } \\
\text { customer loyalty. }\end{array}$ & $\begin{array}{l}\text { Analysis to understand and } \\
\text { improve chatbot dialogue to } \\
\text { improve the customer } \\
\text { experience. }\end{array}$ & $\begin{array}{l}\text { The need for diligence in } \\
\text { chatbot training to } \\
\text { optimize service. } \\
\text { Involve inter-disciplinary } \\
\text { teams in training chatbots } \\
\text { to optimize the chatbot } \\
\text { service. }\end{array}$ \\
\hline
\end{tabular}


Table 2. Cont.

\begin{tabular}{|c|c|c|c|c|c|}
\hline Construct & Definition & Found Articles & Findings/Comments & Future Research & Practical Implications \\
\hline $\begin{array}{c}\text { Chatbots: } \\
\text { System quality } \\
\text { Included in } 8 \text { studies }\end{array}$ & $\begin{array}{l}\text { System quality consists of the } \\
\text { dimensions: accuracy, response } \\
\text { time, usability, reliability, } \\
\text { availability, and adaptability to } \\
\text { measure technical success [29]. }\end{array}$ & $\begin{array}{l}\text { Brandtzaeg and Følstad [5]; } \\
\text { Trivedi [29]; Yen and Chiang [37]; } \\
\text { Akhtar et al. [38]; Følstad and } \\
\text { Skjuve [40]; Følstad et al. [46]; } \\
\text { Gnewuch et al. [49]; } \\
\text { Ashfaq et al. [54]. }\end{array}$ & $\begin{array}{l}\text { System quality has a significant } \\
\text { relationship with customer } \\
\text { experience, which influences } \\
\text { customer loyalty. A chatbots' } \\
\text { response time represents a social } \\
\text { signal that elicits social responses } \\
\text { shaped by social expectations. } \\
\text { Dynamic response delays increase } \\
\text { an individuals' perception of } \\
\text { humanness in a chatbot and, in } \\
\text { turn, lead to greater customer } \\
\text { satisfaction. }\end{array}$ & $\begin{array}{l}\text { Further research more } \\
\text { different types of response } \\
\text { delay by chatbots and their } \\
\text { effects, e.g., dependent on the } \\
\text { text length, static response } \\
\text { delays. }\end{array}$ & $\begin{array}{l}\text { The paper examines the } \\
\text { importance of system } \\
\text { quality toward creating a } \\
\text { customer experience. To } \\
\text { ensure that, the chatbots } \\
\text { need to be highly } \\
\text { relevant, reliable, and } \\
\text { offer information quickly. } \\
\text { Users often feel like the } \\
\text { chatbot will harm their } \\
\text { privacy. Companies } \\
\text { should make the } \\
\text { customers aware of the } \\
\text { ease and risk-free use. }\end{array}$ \\
\hline $\begin{array}{l}\text { Chatbots: } \\
\text { Information quality } \\
\text { Included in } 3 \text { studies }\end{array}$ & $\begin{array}{l}\text { Provide customers with clear, } \\
\text { relevant, and valuable } \\
\text { information [29]. }\end{array}$ & $\begin{array}{l}\text { Brandtzaeg and Følstad [5]; } \\
\text { Trivedi [29]; Følstad and } \\
\text { Skjuve [40]. }\end{array}$ & $\begin{array}{l}\text { The customer experience of using } \\
\text { chatbots leads to satisfaction and } \\
\text { loyalty for the organization. }\end{array}$ & $\begin{array}{l}\text { Further analyze the age, } \\
\text { gender, background } \\
\text { differences of the } \\
\text { understanding in chatbots } \\
\text { and the experience with } \\
\text { chatbots. }\end{array}$ & $\begin{array}{l}\text { Companies should ensure } \\
\text { that chatbots offer highly } \\
\text { relevant, reliable, and } \\
\text { quick information to } \\
\text { consumers at the right } \\
\text { time and the place where } \\
\text { the customer needs it. }\end{array}$ \\
\hline $\begin{array}{l}\text { Complaint handling } \\
\text { Included in } 4 \text { studies }\end{array}$ & $\begin{array}{l}\text { Handling customer complaints } \\
\text { within an organization and } \\
\text { helping the customers out. }\end{array}$ & $\begin{array}{l}\text { Carvajal [25]; Chung et al. [31]; } \\
\text { Yen and Chiang [37]; Cheng and } \\
\text { Jiang [56]. }\end{array}$ & $\begin{array}{l}\text { Chatbots offer customers an easier } \\
\text { way to send their complaints to the } \\
\text { company. Chatbots could decrease } \\
\text { duplicate complaints by suggesting } \\
\text { similar complaints to their } \\
\text { customers. }\end{array}$ & $\begin{array}{l}\text { Test chatbots in different } \\
\text { contexts and different types } \\
\text { of websites in terms of } \\
\text { complaint handling. }\end{array}$ & $\begin{array}{l}\text { In terms of complaint } \\
\text { handling, companies } \\
\text { could make use of } \\
\text { chatbots as first-line } \\
\text { support. }\end{array}$ \\
\hline $\begin{array}{l}\text { Personalization } \\
\text { Included in } 6 \text { studies }\end{array}$ & $\begin{array}{l}\text { Tailored communication based } \\
\text { on information an organization } \\
\text { has learned about an } \\
\text { individual. }\end{array}$ & $\begin{array}{l}\text { Carvajal [25]; Chung et al. [31]; } \\
\text { Akhtar et al. [38]; Przegalinska } \\
\text { et al. [42]; Hwang et al. [51]; } \\
\text { Ashfaq et al. [54]. }\end{array}$ & $\begin{array}{l}\text { Chatbots can satisfy customers by } \\
\text { offering personalized service and } \\
\text { real-time conversation. } \\
\text { Human-like chatbots with a } \\
\text { personal approach have a positive } \\
\text { influence on customer experience. }\end{array}$ & $\begin{array}{l}\text { Further analyze how chatbots } \\
\text { can make personal } \\
\text { approaches. }\end{array}$ & $\begin{array}{l}\text { Find the right balance } \\
\text { between privacy issues } \\
\text { and personalization. }\end{array}$ \\
\hline
\end{tabular}


Table 2. Cont.

Construct Definition

As a company, finding the right balance for

customers in terms of

Concerns about the exposure of Mende et al. [26]; Sidaoui et al into the background in the face of a reward or offer [32]. personal information. At the same time, those concerns fade

[27]; Kokolakis [32]; Yen and

Chiang [37]; Kormpho et al. [41]

Privacy paradox Included in 9 studies
Przegalinska et al. [42]; Cheng

and Jiang [56]; Nordheim et al.

[57]; Martin et al. [58].
Individuals might trust machines even more than personal

information humans, with users providing more personal

information even when they are concerned about their privacy.
Further analyze privacy paradox with chatbots and

explore the relationship

between privacy concerns,

machine heuristic and

privacy protection behaviors. their personal

information and exposing this in exchange for an offer.

There are privacy

concerns about chatbots because of unawareness.

When customers have more knowledge about chatbots, they will have fewer trust issues. 


\section{Selected papers: Year of publication}

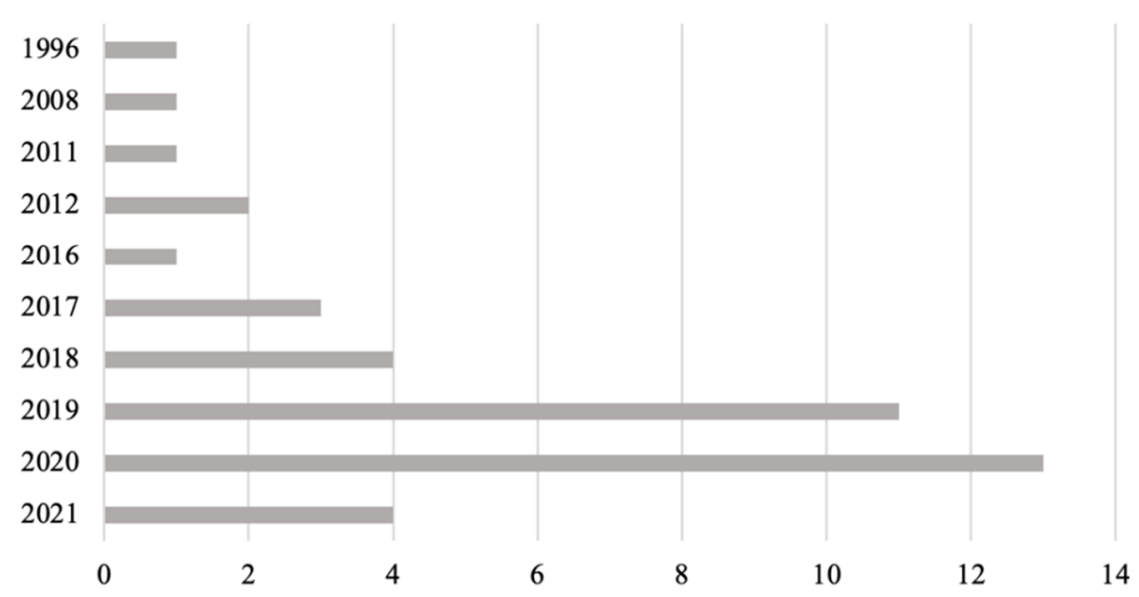

Figure 5. Year of publication of the selected papers.

\section{Top 5 Journals}

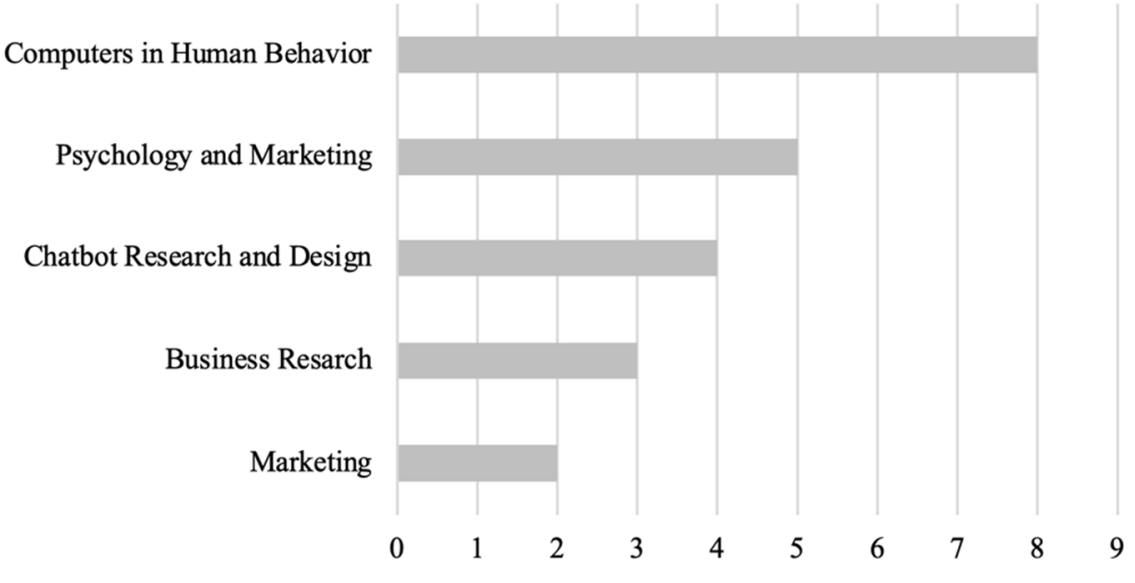

Figure 6. Visualization of the top 5 used Journals.

\subsection{Thematic Analysis}

4.2.1. The Drivers of Customer Loyalty: Satisfaction, Trust, and Commitment

As stated earlier, customer satisfaction, trust, and commitment are the three main drivers of customer loyalty [16,17]. Customer satisfaction is a crucial predictor in fostering the retention of customers [18]. At the same time, customer satisfaction influences customer trust, which both affect customer commitment [17]. In turn, customer loyalty has a significant relation with profitability [7] and is therefore highly relevant for every organization [9]. To satisfy the customers and raise the organization's overall customer satisfaction, a good customer experience is necessary [18]. Therefore, customer experience is during this study seen as a predictor of customer satisfaction, which is in line with multiple selected studies during the literature review search process.

4.2.2. The Role of Chatbots within Customer Experience: System Quality, Service Quality, and Information Quality

With the introduction of chatbots, companies aim to provide their customers with a good customer experience, wherein the chatbot provides a new layer of fast service and relevant information on the internet at any time, from any location [30,33]. Multiple studies stated that integrating a chatbot in a website positively affects the customer experience [10,29,37]. Trivedi [29] citing DeLone and McLean [28], claimed that system quality, service quality, and information quality are critical dimensions for chatbots to create a good 
customer experience that leads to customer satisfaction. This is in line with a study by Ashfaq and colleagues [54].

By diving into the underlying five dimensions of system quality, Trivedi mentioned that individuals use Information Technology systems, such as chatbots, to perform tasks effectively and efficiently [29]. As system quality measures the technical success of the chatbot, 24/7 availability and reliable information at the right place and time are essential to comply with the customer expectations [29]. Users expect information systems to constantly work on every internet connection [29]. The same applies to the adaptability of a chatbot, which means that the developers of the chatbots need to keep their systems up-to-date and need to adapt to necessary developments in the environment. The same study by Trivedi stated that responding as quickly as possible increases the customer experience and that delays negatively impact the customer experience. However, Gnewuch and colleagues declared that being faster is not always better [49]. The results of their study proved that chatbots with dynamic response delays have a positive effect on the customer experience. The reason for this outcome is that dynamically delayed messages from chatbots were perceived as more natural and human-like than instantly sent messages [55]. Chatbots have the purpose of providing the customers with a good experience on a website or app while helping the customers with their comments and or questions in real-time [38]. Ashfaq and colleagues declared that chatbots are used to make it easier for both the customers and organizations because of the accessibility, response time, and availability [54]. That is in line with the studies by Ba and Johansson and Van Der Goot and Pilgrim which declared that a website's ease of use leads to a more extraordinary customer experience [39,59]. At the same time, when individuals perceive the use of a chatbot as complex, the consumer experience is affected negatively [29].

As described earlier, the quality of the information sent by the chatbot is of high importance. The information must be accurate, relevant, and valuable. If the chatbot does not understand the customer and provides the wrong information, the accuracy and reliability failed, which gives the customer a bad experience $[29,60]$. Other studies stated that a response that was not that accurate enough is not immediately linked to a bad experience, as long as the chatbot provided a follow-up conversation with a human agent $[38,40]$.

Service quality consists of both information and system quality and refers to the assurance, responsiveness, and empathy during a conversation [29]. Van Vuuren et al. cited Balaji by stating a significant relationship between the total perceived quality and customer experience and, in turn, on customer satisfaction [17]. Besides, chatbots impact stronger on word-of-mouth and intention to reuse [50]. Overall, if a chatbot works (system quality), is accurate and provides quality information (information quality), and lastly, provides a good service (service quality), the customer experience will stimulate a consumer to continue using chatbots in the future.

\subsubsection{Complaint Handling}

Complaint handling might be one of the most critical factors to gain customer experience, from minor to big complaints. It is crucial to handle complaints as fast as possible to keep the customer satisfied [41]. Even due to handling complaints, a company can improve the quality of its service $[25,41]$. As multiple studies described, a chatbot serves as an excellent way to support customers. According to Hwang et al., customer service by chatbots needs to involve responsiveness, customization and guarantee a good customer experience to satisfy the users [51]. That statement is similar to studies by Chung and colleagues and Trivedi $[29,31]$. Besides, exceeding customers' expectations while taking care of their problems positively affects the customer experience and satisfaction [51]. Cheng and Jiang stated that chatbots might be better at problem-solving than human agents because chatbots are more accurate and efficient [56]. 


\subsubsection{Privacy Paradox and Personalization}

An experiment by Brandtzaeg and Følstad revealed that ease of use, speed, and convenience are the main reasons customers could use a chatbot [5]. Mentioning this, productivity seems to be a fundamental reason to make use of a chatbot. Besides, the results of the experiment by Brandtzaeg and Følstad declared that the assistance and access to information that chatbots provide were reasons to use a chatbot. Although chatbots are predicted to play a significant key role nowadays and in future customer support, researchers noticed that the chatbot adoption among consumers is lower than expected [57]. Reasons for the low chatbot adaption might be that conversations with chatbots are perceived as unnatural, impersonal, and too informal [61]. Besides, Nordheim and colleagues' experiment showed that the majority would use the innovative chatbot [57]. However, not all their participants adopted the chatbot; about one-third of their participants did not want to communicate with the chatbot, mainly because it would cost individuals jobs. At the same time, privacy concerns lead to resistance of chatbots, and in turn to negative usage frequency [62].

The construct privacy paradox can be related to customer trust [58,63]. Websites that offer personalized services might create concerns about the collected personal information $[42,63,64]$. The social presence of a chatbot is a significant driver for trust on a website [43-46]. At the same time, those personalized services might bring convenience while using a website [56]. For the use of chatbots, trust is a crucial factor because users do not want to share too much personal information if they have privacy concerns $[5,56,65]$. An essential part of trust consists of anthropomorphism, which is all about attributing human traits to chatbots [66]. For instance, if a chatbot is more human-like and approaches customers personally, it can reduce the privacy issues and raise the trust in the chatbot $[42,46,67]$. Przegalinska and colleagues argued that individuals nowadays might trust information systems, such as chatbots, more than humans because automation might make fewer mistakes [42]. Araujo stated that a human-like conversation felt better for customers and is enlarging customer trust [43]. Besides, giving the chatbot a name and image fosters the chatbot's human likeness [46].

Chatbots can offer a new dimension of support by providing personalized service where customers' needs are met anytime and anywhere [31]. Stating this, the personalization of chatbots is playing an increasingly important role because multiple studies argued that customers prefer personalized conversation with chatbots $[38,47,52]$. To personalize a chatbot to make it more human-like [68], its language style needs to be altered [51,61,67]. Overall, chatbots' human-like and personalized approach has a significant impact on the customer experience, which in turn can lead to customer loyalty $[25,69]$.

\subsubsection{Customer Experience and Customer Loyalty}

Due to the found literature of the selected papers, a connection between customer experience and customer loyalty can be made. A chatbot with high system quality and high-quality service and information leads to a more remarkable customer experience. In turn, when customers are experiencing good service, they are satisfied with the service they received [48]. Based on this customer satisfaction, the customers will get more trust in that specific organization, leading to commitment. Satisfaction, trust, and commitment in and with a company have customer loyalty as a result [7]. Figure 7 visualizes the connection between customer experience and customer loyalty. 


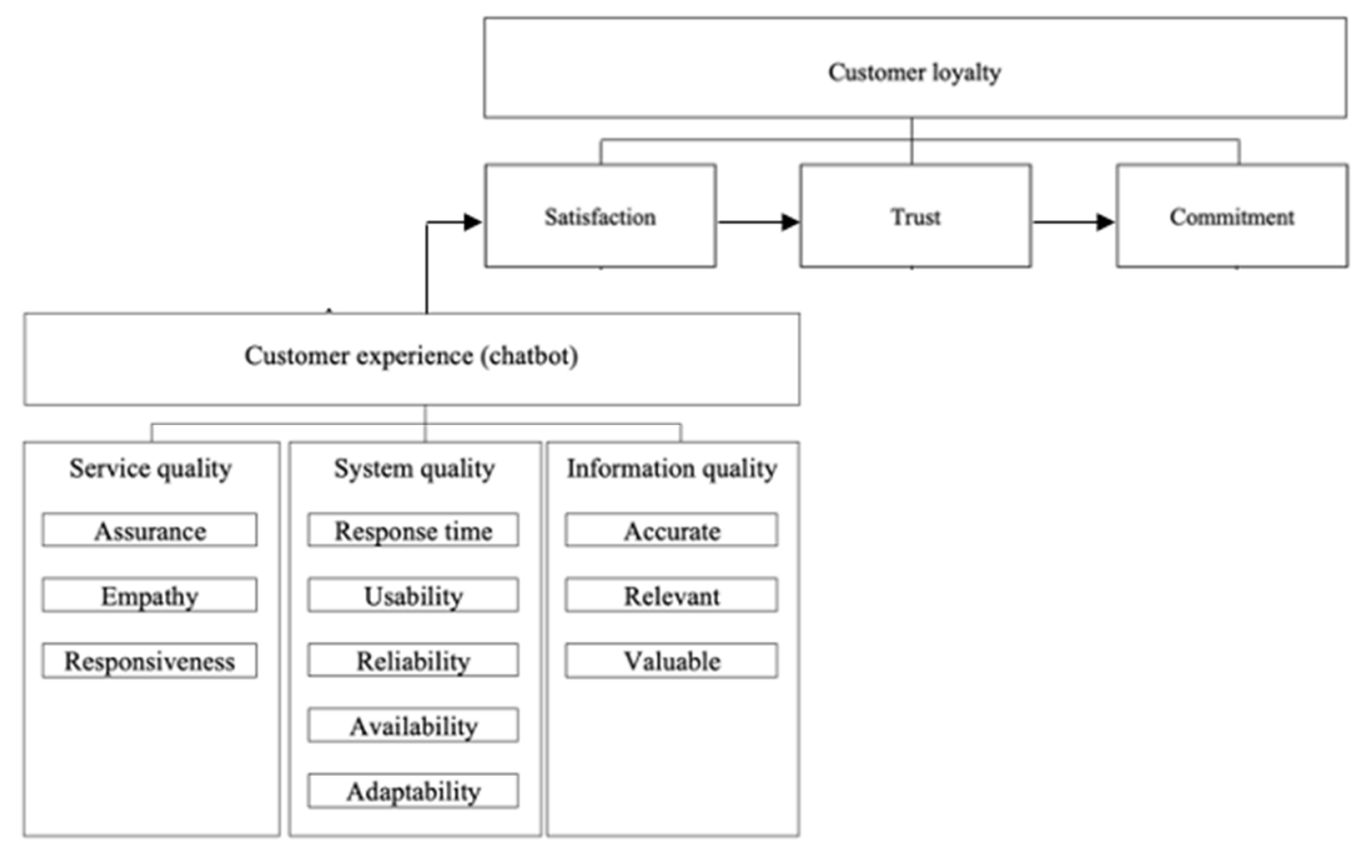

Figure 7. Customer experience and customer loyalty.

\section{Discussion}

The purpose of this study was to investigate the influence of chatbots on customer loyalty. The results showed that companies should create satisfaction, trust, and commitment among and with their customer. Multiple scientific articles indicated that when customers have a good experience with an organization, they will be satisfied with that experience. That means that there is a link between customer experience and customer satisfaction. On the other hand, a satisfied customer gains confidence in a future service at an organization, which leads to customer trust [43]. The convergence of satisfaction and trust in a company has customer commitment as a result. These three drivers together make it able to create customer loyalty [17].

The chatbot market is on the rise, and multiple studies found that chatbots can play a valuable role in providing customers with a good experience [30]. Multiple studies declared that chatbots could give a good customer experience if they meet the three dimensions: system quality, service quality, and information quality [29,54]. Within these dimensions, complaint handling is one of the most common occurrences to make us of a chatbot. In the end, when the expectation of a chatbot user with a complaint is exceeded, the customer has a good experience leading to customer satisfaction. Based on the findings during this systematic literature review, there can be stated that there is a connection between customer experience and customer satisfaction when making use of a chatbot, which in turn leads to customer loyalty. Mentioning this, it is very likely that there is a positive relation between chatbot use and customer loyalty.

While chatbots are predicted to play an important key role in current and future customer support, researchers have noted that the adoption of chatbots among consumers is lower than expected [57]. Studies showed that the low adoption has to do with the fact that chatbots are often unnaturally and impersonal [61,70]. At the same time, several studies reported that many customers have privacy concerns because too much personal data is collected. Customers are afraid to share too much personal information. Other studies examined customers prefer human-like chatbots that offer a personal approach and a tailored message. If a chatbot has a human-like appearance-including name and image - and it approaches customers personally, it might reduce the privacy issues and, in turn, raise the trust in the chatbot [46,71]. Besides, Borau and colleagues argued that female gendering increases humanness perceptions of bots and acceptance of artificial intelligence [72]. 
To make a chatbot more personal, the language style must be changed [53]. Studies have indicated that human-like chatbots lead to greater satisfaction and trust among customers, leading to greater adoption of the chatbot. In general, chatbots' human and personal approach has a significant impact on the customer experience, which in turn can lead to customer loyalty. Figure 4 visualizes the connection between customer experience and customer loyalty by chatbots.

\subsection{Practical Implications}

This study obtained insights into the relevance of chatbots used by companies. Companies should optimize the customer experience to raise their customer satisfaction. To optimize the service, there want for diligence in training chatbots is needed. Involving interdisciplinary teams in training chatbots to optimize the customer experience would be relevant. This study highlighted the importance of system quality, information quality, and service quality toward creating a customer experience. Companies should ensure that their chatbot offers quick information that is relevant and reliable to their customers at the right time and place where the customers need it.

Users often feel like the chatbot will harm their privacy. Companies should make the customers aware of the ease and risk-free use. The privacy concerns about chatbots are because of unawareness as well. When customers have more knowledge about chatbots, they will have fewer trust issues. It is crucial to find the right balance for customers in terms of their personal information and expose this in exchange for an offer. Overall, companies should put effort into winning customer trust by sharing reviews and being transparent.

\subsection{Theoretical Implications and Future Research}

Several studies have linked customer experience and customer loyalty, but not many studies have made the connection between chatbots and customer loyalty. This study provides more insight into the impact of chatbots on customer loyalty due to their customer experience. There is still much uncertainty in chatbots among customers in terms of customer trust. As mentioned in the limitations, there are no statements about the impact of chatbots on customer loyalty in different generations. The chatbot and its trust reduction may be more efficient in complex websites or with older people. A recommendation is to research further the differences of age, gender, and background differences among customers in understanding the chatbot and their experience while using it. Privacy-related, it would be helpful to analyze the privacy paradox further and explore the relation between privacy issues, machine heuristics, and privacy protection behavior.

The most important for greater customer satisfaction is helping the customer out and giving them a good experience. Multiple studies found evidence that chatbots improve the customer experience. Although this study stated that it is very likely that chatbots positively affect customer loyalty, only desk research is used. For future research, a qualitative longitudinal study is recommended to prove this relation.

The results of this study showed some contrasting findings on the response delay by chatbots and their effects. Some studies showed that instant response would increase the customer experience, where other studies indicated that a dynamic delayed response would create a greater customer experience because it gives a human-like and natural feeling. It is recommended to analyze these different findings further.

Previous studies indicated that human-like chatbots lead to greater satisfaction and trust among customers, leading to greater adoption of the chatbot. For instance, when a chatbot has a human-like appearance and a human-like language style, it leads to greater customer satisfaction because the conversation becomes more natural. For future research, it is recommended to further investigate the role and attribution of human-like features on chatbots and what the effect of these anthropomorphic chatbots is on the perceived social presence and adoption of chatbots. 


\subsection{Limitations}

This study includes several limitations. Despite studying and aggregating the results of papers, no statements can be made during this study about the impact of chatbots on customer loyalty at different ages of customers. In addition, the selected scientific papers did not illustrate the impact a chatbot can have in different contexts and functions, such as support chatbots, skills chatbots, and assistant chatbots.

\section{Conclusions}

This systematic literature review obtains insight into the influence of chatbots on customer loyalty and how chatbots can respond to the changing needs of today's customers. The endless online offer and the ease of online developments have changed the wishes and needs of the customer today, which has changed the achievement of customer loyalty as well. The "new customer in 2022" expects to be able to reach a company anytime and anywhere, regardless of time, location, and channel, and expects to spend less time doing so. In this digital age where the continuous availability of businesses is crucial, optimizing the customer experience is more essential than ever to achieve customer loyalty.

This systematic literature review, as a methodological technique, provides an overview of the state of the art of the influence of chatbots on customer loyalty and boosts researchers to continue with empirical studies to advance in this line of research. More and more companies have implemented chatbots on their websites to provide support to their visitors all day. System quality, service quality, and information quality are crucial dimensions that a chatbot must meet to provide good customer experience. Further, a good customer experience results from a focus on customer satisfaction. Because satisfaction leads, in turn, to loyalty, a chatbot likely has an impact on customer loyalty.

Although the chatbot market is on the rise, there has been low adoption of the chatbot. Customers argue that a chatbot is unnatural and impersonal. To make a chatbot more personal, companies can alter the language style. Human-like chatbots lead to greater satisfaction and trust among customers, leading to greater adoption of the chatbot. Therefore, the role of anthropomorphism and the perceived social presence of chatbots should be further studied. Besides, some customers suffer from privacy paradoxes because of personalization. Companies should find the balance for customers regarding their personal information and expose this in exchange for an offer.

Author Contributions: Conceptualization, L.J; methodology, L.J.; assistant in conceptualization and validation, C.H. and E.C.; investigation, L.J.; resources, L.J.; writing-original draft preparation, L.J.; writing - review and editing, L.J.; supervision, C.H. and E.C. All authors have read and agreed to the published version of the manuscript.

Funding: This research received no external funding.

Institutional Review Board Statement: Not applicable.

Informed Consent Statement: Not applicable.

Data Availability Statement: Not applicable.

Conflicts of Interest: The authors declare no conflict of interest.

\section{References}

1. Maroengsit, W.; Piyakulpinyo, T.; Phonyiam, K.; Pongnumkul, S.; Chaovalit, P.; Theeramunkong, T. A Survey on Evaluation Methods for Chatbots. In Proceedings of the 2019 7th International Conference on Information and Education Technology-ICIET 2019, Aizu-Wakamatsu, Japan, 29-31 March 2019; ACM Press: New York, NY, USA, 2019; pp. 111-119.

2. Suwono, L.V.; Sihombing, S.O. Factors Affecting Customer Loyalty of Fitness Centers: An Empirical Study. J. Din. Manaj. 2016, 7, 45. [CrossRef]

3. McLean, G.; Wilson, A. Evolving the online customer experience ... is there a role for online customer support? Comput. Hum. Behav. 2016, 60, 602-610. [CrossRef]

4. Siswi, A.A.; Wahyono, W. The Role of Customer Satisfaction in Increasing Customer Loyalty. Manag. Anal. J. 2020, 9, 17-25. [CrossRef] 
5. $\quad$ Brandtzaeg, P.B.; Følstad, A. Why People Use Chatbots. Internet Sci. 2017, 377-392, 377-392. [CrossRef]

6. Ameen, N.; Hosany, S.; Tarhini, A. Consumer interaction with cutting-edge technologies: Implications for future research. Comput. Hum. Behav. 2021, 120, 106761. [CrossRef]

7. Hallowell, R. The relationships of customer satisfaction, customer loyalty, and profitability: An empirical study. Int. J. Serv. Ind. Manag. 1996, 7, 27-42. [CrossRef]

8. MSI. Research Priorities 2020-2022. Massachusetts, in Marketing Science Institute. Available online: https://www.msi.org/wpcontent/uploads/2020/06/MSI_RP20-22.pdf (accessed on 12 January 2022).

9. Innis, D.E.; La Londe, B.J. Modelling the Effects of Customer Service Performance on Purchase Intentions in the Channel. J. Mark. Theory Pract. 1994, 2, 45-60. [CrossRef]

10. Hoyer, W.D.; Kroschke, M.; Schmitt, B.; Kraume, K.; Shankar, V. Transforming the Customer Experience Through New Technologies. J. Interact. Mark. 2020, 51, 57-71. [CrossRef]

11. Lemon, K.N.; Verhoef, P.C. Understanding Customer Experience Throughout the Customer Journey. J. Mark. 2016, 80, 69-96. [CrossRef]

12. Crolic, C.; Thomaz, F.; Hadi, R.; Stephen, A.T. Blame the Bot: Anthropomorphism and Anger in Customer-Chatbot Interactions. J. Mark. 2021, 86, 132-148. [CrossRef]

13. Gartner Says 25 Percent of Customer Service Operations Will Use Virtual Customer Assistants by 2020. (2018, February 19). Gartner. Available online: https:/ /www.gartner.com/en/newsroom/press-releases/2018-02-19-gartner-says-25-percent-ofcustomer-service-operations-will-use-virtual-customer-assistants-by-2020. (accessed on 3 April 2021).

14. Fornell, C. A National Customer Satisfaction Barometer: The Swedish Experience. J. Mark. 1992, 56, 6. [CrossRef]

15. McMullan, R.; Gilmore, A. Customer loyalty: An empirical study. Eur. J. Mark. 2008, 42, 1084-1094. [CrossRef]

16. Pratminingsih, S.A.; Lipuringtyas, C.; Rimenta, T. Factors Influencing Customer Loyalty Toward Online Shopping. Int. J. Trade Econ. Financ. 2013, 4, 104-110. [CrossRef]

17. Van Vuuren, T.; Roberts-Lombard, M.; Van Tonder, E. Customer satisfaction, trust and commitment as predictors of customer loyalty within an optometric practice environment. South. Afr. Bus. Rev. 2012, 16, 81-96.

18. Bryant, A.; Colledge, B. Trust in electronic commerce business relationships. J. Electron. Commer. Res. 2002, 3, 32-39.

19. Herrmann, A.; Xia, L.; Monroe, K.B.; Huber, F. The influence of price fairness on customer satisfaction: An empirical test in the context of automobile purchases. J. Prod. Brand Manag. 2007, 16, 49-58. [CrossRef]

20. Kotler, P.; Armstrong, G. Principles of Marketing; Pearson Education: London, UK, 2010.

21. Leck, J.D.; Saunders, D.M. Hirschman's loyalty: Attitude or behavior? Empl. Responsib. Rights J. 1992, 5, 219-230. [CrossRef]

22. Rust, R.T.; Zahorik, A.J. Customer satisfaction, customer retention, and market share. J. Retail. 1993, 69, 193-215. [CrossRef]

23. Shoemaker, S.; Lewis, R.C. Customer loyalty: The future of hospitality marketing. Int. J. Hosp. Manag. 1999, 18, 345-370. [CrossRef]

24. Lake, D.G. Winning the service game, by Benjamin Schneider and David E. Bowen, Boston: Harvard Business School Press. Hum. Res. Manag. 1995, 34, 463-465. [CrossRef]

25. Carvajal, S.A. The impact of personalization and complaint handling on customer loyalty. Afr. J. Bus. Manag. 2011, 5, 13187-13196. [CrossRef]

26. Mende, M.; Scott, M.L.; Van Doorn, J.; Grewal, D.; Shanks, I. Service Robots Rising: How Humanoid Robots Influence Service Experiences and Elicit Compensatory Consumer Responses. J. Mark. Res. 2019, 56, 535-556. [CrossRef]

27. Sidaoui, K.; Jaakkola, M.; Burton, J. AI feel you: Customer experience assessment via chatbot interviews. J. Serv. Manag. 2020, 31, 745-766. [CrossRef]

28. Delone, W.H.; McLean, E.R. Information Systems Success: The Quest for the Dependent Variable. Inf. Syst. Res. 1992, 3, 60-95. [CrossRef]

29. Trivedi, J. Examining the Customer Experience of Using Banking Chatbots and Its Impact on Brand Love: The Moderating Role of Perceived Risk. J. Internet Commer. 2019, 18, 91-111. [CrossRef]

30. Hagberg, J.; Jonsson, A.; Egels-Zandén, N. Retail digitalization: Implications for physical stores. J. Retail. Consum. Serv. 2017, 39, 264-269. [CrossRef]

31. Chung, M.; Ko, E.; Joung, H.; Kim, S.J. Chatbot e-service and customer satisfaction regarding luxury brands. J. Bus. Res. 2020, 117, 587-595. [CrossRef]

32. Kokolakis, S. Privacy attitudes and privacy behaviour: A review of current research on the privacy paradox phenomenon. Comp. Sec. 2017, 64, 122-134. [CrossRef]

33. Hokanson, S. The deeper you analyze, the more you satisfy customers. Mark. News 1995, $29,16$.

34. Lyngdoh, T.; Chefor, E.; Hochstein, B.; Britton, B.P.; Amyx, D. A systematic literature review of negative psychological states and behaviors in sales. J. Bus. Res. 2021, 122, 518-533. [CrossRef]

35. Hoy, M.B. Alexa, Siri, Cortana, and More: An Introduction to Voice Assistants. Med Ref. Serv. Q. 2018, 37, 81-88. [CrossRef] [PubMed]

36. Need-to-Know Chatbot Statistics in 2021. (2020, May 6). ChatBot. Available online: https://www.chatbot.com/blog/chatbotstatistics / (accessed on 3 April 2021).

37. Yen, C.; Chiang, M.-C. Trust me, if you can: A study on the factors that influence consumers' purchase intention triggered by chatbots based on brain image evidence and self-reported assessments. Behav. Inf. Technol. 2021, 40, 1177-1194. [CrossRef] 
38. Akhtar, M.; Neidhardt, J.; Werthner, H. The Potential of Chatbots: Analysis of Chatbot Conversations. In Proceedings of the 2019 IEEE 21st Conference on Business Informatics (CBI), Moscow, Russia, 15-17 July 2019; Volume 1, pp. 397-404.

39. Ba, S.; Johansson, W.C. An Exploratory Study of the Impact of e-Service Process on Online Customer Satisfaction. Prod. Oper. Manag. 2008, 17, 107-119. [CrossRef]

40. Følstad, A.; Skjuve, M. Chatbots for customer service. In Proceedings of 1st International Conference on Conversational User Interfaces-CUI '19; Dublin, Ireland, 22-23 August 2019, ACM Press: New York, NY, USA, 2019; Volume 19, pp. 1-9.

41. Kormpho, P.; Liawsomboon, P.; Phongoen, N.; Pongpaichet, S. Smart Complaint Management System. In Proceedings of the 2018 Seventh ICT International Student Project Conference (ICT-ISPC), Nakhonpathom, Thailand, 11-13 July 2018; pp. 1-6.

42. Przegalinska, A.; Ciechanowski, L.; Stroz, A.; Gloor, P.; Mazurek, G. In bot we trust: A new methodology of chatbot performance measures. Bus. Horiz. 2019, 62, 785-797. [CrossRef]

43. Araujo, T. Living up to the chatbot hype: The influence of anthropomorphic design cues and communicative agency framing on conversational agent and company perceptions. Comput. Hum. Behav. 2018, 85, 183-189. [CrossRef]

44. Chattaraman, V.; Kwon, W.-S.; Gilbert, J.E. Virtual agents in retail web sites: Benefits of simulated social interaction for older users. Comput. Hum. Behav. 2012, 28, 2055-2066. [CrossRef]

45. Toader, D.-C.; Boca, G.; Toader, R.; Măcelaru, M.; Toader, C.; Ighian, D.; Rădulescu, A.T. The Effect of Social Presence and Chatbot Errors on Trust. Sustainability 2019, 12, 256. [CrossRef]

46. Følstad, A.; Nordheim, C.B.; Bjørkli, C.A. What Makes Users Trust a Chatbot for Customer Service? An Exploratory Interview Study. Internet Sci. 2018, 194-208, 194-208. [CrossRef]

47. Youn, S.; Jin, S.V. "In A.I. we trust?" The effects of parasocial interaction and technopian versus luddite ideological views on chatbot-based customer relationship management in the emerging "feeling economy". Comput. Hum. Behav. 2021, 119, 106721. [CrossRef]

48. Nguyen, T.; Quach, S.; Thaichon, P. The effect of AI quality on customer experience and brand relationship. J. Consum. Behav. 2021. [CrossRef]

49. Gnewuch, U.; Morana, S.; Adam, M.; Maedche, A. Faster is not always better: Understanding the effect of dynamic re-sponse delays in human-chatbot interaction. In Proceedings of the 26th European Conference on Information Systems: Beyond Digitization-Facets of Socio-Technical Change, ECIS 2018, Portsmouth, UK, 23-28 June 2018.

50. Rossmann, A.; Zimmermann, A.; Hertweck, D. The Impact of Chatbots on Customer Service Performance. In Advances in Intelligent Systems and Computing; Springer: Singapore, 2020; pp. 237-243.

51. Hwang, S.; Kim, B.; Lee, K. A Data-Driven Design Framework for Customer Service Chatbot. Lect. Notes Comput. Sci. 2019, 222-236. [CrossRef]

52. Elsholz, E.; Chamberlain, J.; Kruschwitz, U. Exploring Language Style in Chatbots to Increase Perceived Product Value and User Engagement. In Proceedings of the 2019 Conference on Human Information Interaction and Retrieval, Glasgow, UK, 10-14 March 2019; ACM Press: New York, NY, USA, 2019; pp. 301-305.

53. Johari, N.M.; Zaman, H.B.; Nohuddin, P.N.E. Ascertain Quality Attributes for Design and Development of New Improved Chatbots to Assess Customer Satisfaction Index (CSI): A Preliminary Study. In Lecture Notes in Computer Science; Springer: Singapore, 2019; pp. 135-146.

54. Ashfaq, M.; Yun, J.; Yu, S.; Loureiro, S.M.C. I, Chatbot: Modeling the determinants of users' satisfaction and continuance intention of AI-powered service agents. Telemat. Inform. 2020, 54, 101473. [CrossRef]

55. Kvale, K.; Sell, O.A.; Hodnebrog, S.; Følstad, A. Improving Conversations: Lessons Learnt from Manual Analysis of Chatbot Dialogues. Lect. Notes Comput. Sci. 2020, 187-200. [CrossRef]

56. Cheng, Y.; Jiang, H. How Do AI-driven Chatbots Impact User Experience? Examining Gratifications, Perceived Privacy Risk, Satisfaction, Loyalty, and Continued Use. J. Broadcast. Electron. Media 2020, 64, 592-614. [CrossRef]

57. Nordheim, C.B.; Følstad, A.; Bjørkli, C.A. An Initial Model of Trust in Chatbots for Customer Service-Findings from a Questionnaire Study. Interact. Comput. 2019, 31, 317-335. [CrossRef]

58. Martin, K.D.; Kim, J.J.; Palmatier, R.W.; Steinhoff, L.; Stewart, D.W.; Walker, B.A.; Wang, Y.; Weaven, S.K. Data Privacy in Retail. J. Retail. 2020, 96, 474-489. [CrossRef]

59. Van der Goot, M.J.; Pilgrim, T. Exploring Age Differences in Motivations for and Acceptance of Chatbot Communication in a Customer Service Context. Lect. Notes Comput. Sci. 2020, 173-186. [CrossRef]

60. Xu, A.; Liu, Z.; Guo, Y.; Sinha, V.; Akkiraju, R. A New Chatbot for Customer Service on Social Media. In Proceedings of the 2017 CHI Conference on Human Factors in Computing Systems, Denver, CO, USA, 6-11 May 2017; ACM Press: New York, NY, USA, 2017; pp. 3506-3510.

61. Liebrecht, C.; Sander, L.; Van Hooijdonk, C. Too Informal? How a Chatbot's Communication Style Affects Brand Attitude and Quality of Interaction. Lect. Notes Comput. Sci. 2021, 16-31. [CrossRef]

62. Rajaobelina, L.; Prom Tep, S.; Arcand, M.; Ricard, L. Creepiness: Its antecedents and impact on loyalty when interacting with a chatbot. Psychol. Mark. 2021, 38, 1-18. [CrossRef]

63. Hallam, C.; Zanella, G. Online self-disclosure: The privacy paradox explained as a temporally discounted balance between concerns and rewards. Comput. Hum. Behav. 2017, 68, 217-227. [CrossRef] 
64. Gutierrez, A.; O’Leary, S.; Rana, N.P.; Dwivedi, Y.K.; Calle, T. Using privacy calculus theory to explore entrepreneurial directions in mobile location-based advertising: Identifying intrusiveness as the critical risk factor. Comput. Hum. Behav. 2019, 95, 295-306. [CrossRef]

65. Rese, A.; Ganster, L.; Baier, D. Chatbots in retailers' customer communication: How to measure their acceptance? J. Retail. Consum. Serv. 2020, 56, 102176. [CrossRef]

66. Van der Goot, M.J.; Hafkamp, L.; Dankfort, Z. Customer Service Chatbots: A Qualitative Interview Study into the Communication Journey of Customers. Lect. Notes Comput. Sci. 2021, 190-204. [CrossRef]

67. Moriuchi, E. An empirical study on anthropomorphism and engagement with disembodied AIs and consumers' re-use behavior. Psychol. Mark. 2021, 38, 21-42. [CrossRef]

68. Go, E.; Sundar, S.S. Humanizing chatbots: The effects of visual, identity and conversational cues on humanness perceptions. Comput. Hum. Behav. 2019, 97, 304-316. [CrossRef]

69. Sheehan, B.; Jin, H.S.; Gottlieb, U. Customer service chatbots: Anthropomorphism and adoption. J. Bus. Res. 2020, 115, 14-24. [CrossRef]

70. Ling, E.C.; Tussyadiah, I.; Tuomi, A.; Stienmetz, J.; Ioannou, A. Factors influencing users' adoption and use of conversational agents: A systematic review. Psychol. Mark. 2021, 38, 1031-1051. [CrossRef]

71. Balakrishnan, J.; Dwivedi, Y.K. Role of cognitive absorption in building user trust and experience. Psychol. Mark. 2021, 38, 643-668. [CrossRef]

72. Borau, S.; Otterbring, T.; Laporte, S.; Wamba, S.F. The most human bot: Female gendering increases humanness perceptions of bots and acceptance of AI. Psychol. Mark. 2021, 38, 1052-1068. [CrossRef] 